\title{
Effectiveness of Polyacrylamide, Wood Shred Mulch, and Pine Needle Mulch as Post-Fire Hillslope Stabilization Treatments in Two Contrasting Volcanic Soils
}

\author{
Jonay Neris ${ }^{1,2, *}$, Stefan H. Doerr ${ }^{1} \mathbb{C D}^{2}$, Jesús S. Notario del Pino ${ }^{2}$, Carmen D. Arbelo ${ }^{2}$ \\ and Antonio Rodríguez-Rodríguez ${ }^{2}$ \\ 1 Department of Geography, College of Science, Swansea University, Swansea SA2 8PP, West Glamorgan, UK; \\ s.doerr@swansea.ac.uk \\ 2 Departamento de Biología Animal y Edafología y Geología, Facultad de Ciencias, \\ Universidad de La Laguna (ULL), Av. Astrofísico Fco. Sánchez s/n, La Laguna 38200, Spain; \\ jnotario@ull.edu.es (J.S.N.d.P.); carbelo@ull.es (C.D.A.); antororo@ull.es (A.R.-R.) \\ * Correspondence: j.neristome@swansea.ac.uk; Tel.: +44-17-9260-2054
}

Received: 5 May 2017; Accepted: 29 June 2017; Published: 12 July 2017

\begin{abstract}
Post-fire hillslope stabilization treatments aim to reduce runoff-erosion risks following forest fires by counteracting the impact of fire on key soil and hillslope properties. Here we evaluate the effectiveness of wood shred mulch, long-leaved pine needle mulch, and polyacrylamide (PAM) in reducing post-fire runoff and erosion in two volcanic soil types of contrasting wettability using rainfall simulations $\left(55 \mathrm{~mm} \mathrm{~h}^{-1}\right.$ for $\left.30 \mathrm{~min}\right)$ at the microplot $\left(0.25 \mathrm{~m}^{2}\right)$ scale. The cover provided by the wood shreds and pine needles led to a reduction of runoff and erosion in both the wettable- $(62 \%$ and $92 \%$, respectively, for wood shreds, and $55 \%$ and $87 \%$, respectively, for needle mulch) and the extremely water-repellent soils ( $44 \%$ and $61 \%$, respectively, for wood shreds). In contrast to what might be expected, PAM did not reduce runoff or erosion when applied to the extremely water-repellent soils, suggesting that PAM should not be applied in this terrain type. Although more research is needed to determine whether the high effectiveness of pine needle mulch and wood shred mulch fully translates to coarser scales, the results are encouraging in terms of these materials' ability to provide effective and relatively economic mitigation treatments for fire-induced runoff-erosion risks in volcanic soils.
\end{abstract}

Keywords: forest fires; emergency treatments; fire-induced risks; runoff-erosion processes; water repellency; forest recovery; volcanic soils

\section{Introduction}

Wildfire can substantially enhance the hydrological and erosional response of forest areas with sometimes serious consequences for the environment, infrastructure, and population, such as flooding, debris flows, and the contamination of rivers and reservoirs [1]. This response is typically triggered by an enhancement of soil water repellency together with a reduction in soil aggregate stability and a decrease in ground cover [1].

Post-fire hillslope stabilization treatments are aimed at counteracting fire-induced impacts on these key hillslope and soil properties [2]. The reduction in protective ground cover by the combustion of the forest canopy and the forest floor is considered the main factor responsible for enhanced erosion events in the post-fire period [3]. To address this, several post-fire hillslope stabilization treatments have recently been developed, including wood-based and agricultural straw mulches. Wood-based mulches (chips, shreds, or strands) show advantages when compared to straw mulches such as: (i) higher density, therefore reducing their redistribution by wind; (ii) free of weed seeds, and; (iii) lower 
transport costs and availability issues since they can be obtained from burned trees or forest-thinning residues [4-6]. However, pre-processing and transport costs can be high particularly when fine fibers are removed to improve effectiveness [5] and when aircraft are used for application [4,7].

An alternative to the wood-based treatments is a pine needle mulch. Pine needles do not require pre-processing treatments, their lower density reduces the transport and application costs when compared to wood mulches, and the natural interlocking of large pine needles can limit the wind redistribution issues of straw mulch [8]. Additionally, its availability can be guaranteed in some regions where the harvesting of pine needles for livestock bedding and agricultural use is an established economic activity. However, pine needle mulch effectiveness has not been widely tested and compared to wood-based mulch performance to date.

Other hillslope stabilization treatments, such as anionic polyacrylamide (PAM) applications, are aimed at increasing the aggregate stability of soils, thereby enhancing infiltration and reducing erosion. PAM has been widely used in irrigated agriculture, but its evaluation in forest soils and fire-affected areas has been limited and some of the results obtained are contradictory (see e.g., $[9,10])$. However, some studies on its performance have suggested that its application can also have an additional positive effect in fire-affected soils that justifies further evaluation: a reduction of soil water repellency [11] that can reduce runoff and erosion risks in extremely water-repellent soils.

Although the application of post-fire hillslope stabilization treatments is widespread in the USA in areas deemed to be at high risk, their application in other countries has been limited to date. This lack of post-fire treatments has led, in some cases, to a risk to lives and resources in particularly vulnerable areas such as those with volcanic soils. For example, in 2009 a severe erosion event occurred in a fire-affected area in volcanic terrain in La Palma (Canary Islands, Spain) that led to damages to infrastructure and affected public safety during the first rainstorm after the fire [12]. Population and infrastructure in volcanic regions, and particularly on volcanic islands, are usually extremely vulnerable to hydrological and erosional events due to their location in, or downstream of, fire-prone steep slopes, and the high population density [13]. Additionally, recent studies have highlighted that fire can lead to major changes in the structural stability of volcanic soils and to a significant reduction of their natural resistance to erosion in undisturbed conditions $[14,15]$. However, the actual hydrological and erosional response of this soil type to the impact of fire and the effectiveness of widely used post-fire hillslope stabilization treatments in these specific conditions have not yet been thoroughly evaluated [12].

This study aimed to address the research gaps identified above by evaluating the impact of fire and the performance of three different post-fire hillslope stabilization treatments (wood shreds, pine needles, and PAM) in fire-affected volcanic soils of contrasting water repellency. The specific objectives were to (i) advance knowledge of the impact of fire on distinctive volcanic soils, and to evaluate; (ii) the performance of wood-based mulch for water-repellent and wettable soils; (iii) the effectiveness of needle-based mulch as substitute for wood-based mulch, and; (iv) the effect of PAM in extremely water-repellent terrain.

\section{Methods}

\subsection{Study Sites}

The study was carried out in Tenerife (Canary Islands, Spain). This volcanic island of $2057 \mathrm{~km}^{2}$ and maximum elevation of $3718 \mathrm{~m}$ above sea level (a.s.l.), is situated between $27^{\circ} 55^{\prime}$ and $28^{\circ} 35^{\prime} \mathrm{N}$ and between $16^{\circ} 05^{\prime}$ and $16^{\circ} 55^{\prime} \mathrm{W}$. Two study sites, Candelaria and Vilaflor, were selected on slopes where wildfire had occurred in forest stands in summer 2015 (Figure 1). 


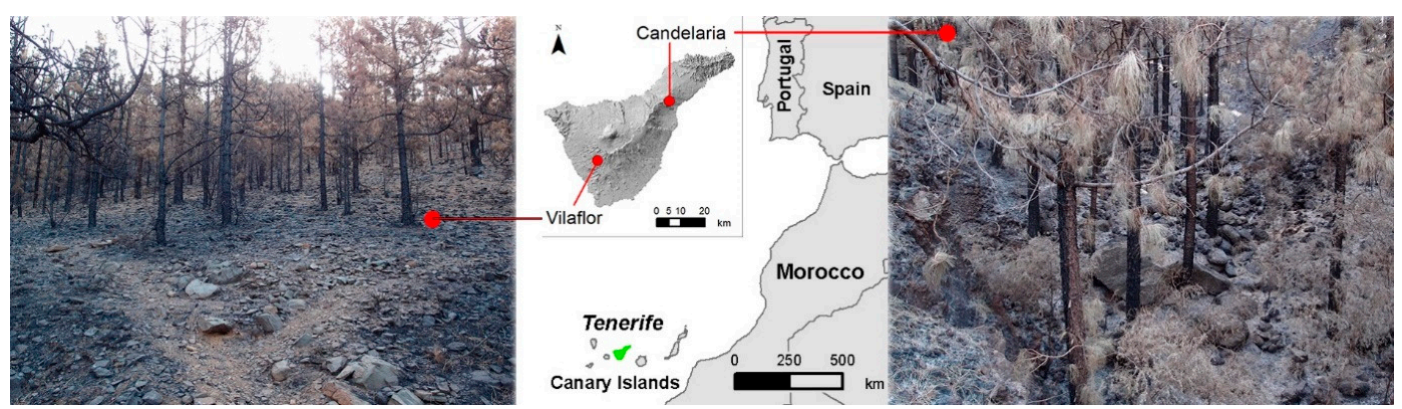

Figure 1. Fire-affected areas in Tenerife (Canary Islands, Spain) examined in this study.

Candelaria is located between 1400 and $1700 \mathrm{~m}$ a.s.l. with vegetation comprising a dense Canary Island pine forest stand (Pinus canariensis). Soils are loam Haplustands and Vitrandic haplustepts developed over 0.7-0.01 million-year-old basaltic pyroclasts and lava flows [16]. Mean annual temperature at the nearest climate station (Gaitero: $28^{\circ} 23^{\prime} 41^{\prime \prime} \mathrm{N}, 16^{\circ} 26^{\prime} 00^{\prime \prime} \mathrm{W} ; 1747 \mathrm{~m}$ a.s.l.) is $12.1^{\circ} \mathrm{C}$, ranging from $6.8^{\circ} \mathrm{C}$ in February and $20.0^{\circ} \mathrm{C}$ in August. Mean annual precipitation is $737 \mathrm{~mm}$, varying between $147 \mathrm{~mm}$ in dry years and $1527 \mathrm{~mm}$ in wet years. On 31 of July 2015 a surface fire affected a relatively small area (5 ha). It consumed or charred the litter and duff, but only scorched the pine canopies and areas where litter and duff were charred, but still recognizable, prevailed. The soil was not strongly affected by the fire and soil burn severity was classified as low-moderate [17]. Ground cover by scorched pine needles increased rapidly from $<10 \% 2$ weeks after the fire to $>90 \%$ 2 months after the fire.

Vilaflor is located between 2025 and $2225 \mathrm{~m}$ a.s.l. with vegetation comprising a dense plantation of Canary Island pine (Pinus canariensis). Soils are loam Dystroxerepts and Xerorthents developed over 1.6-0.7 million-year-old phonolitic lava flows [16]. Mean annual temperature at the nearest climate station (Los Topos: $28^{\circ} 10^{\prime} 18^{\prime \prime} \mathrm{N}, 16^{\circ} 39^{\prime} 05^{\prime \prime} \mathrm{W}, 1831 \mathrm{~m}$ a.s.l.) is $13.9^{\circ} \mathrm{C}$, ranging from $8.9^{\circ} \mathrm{C}$ in February and $21.9^{\circ} \mathrm{C}$ in August. Mean annual precipitation is $297 \mathrm{~mm}$, varying between $51 \mathrm{~mm}$ in dry years and $517 \mathrm{~mm}$ in wet years. On 10 of June 2015 a wildfire affected a 25-ha area, charring or consuming the forest floor and tree canopies. Fuel consumption was greater here compared to Candelaria, but areas where litter and duff were charred but still recognizable also prevailed, and soil burn severity was classified as low-moderate [17]. Ground cover by pine needles was generally $<5 \%$ several months after the fire.

\subsection{Experimental Design}

Field measurements were carried out in December 2015, 4 and 6 months after the fire of Candelaria and Vilaflor, respectively. In the interim, a litter of pine needles from the scorched canopy formed at Candelaria. On the 22 October 2015, a torrential storm with total rainfall depth of $116 \mathrm{~mm}$ and peak 10-min intensity of $27 \mathrm{~mm} \mathrm{~h}^{-1}$ at Candelaria and $82 \mathrm{~mm}$ and $18 \mathrm{~mm} \mathrm{~h}^{-1}$ at Vilaflor occurred. The resulting runoff removed some of the protective ash layer and eroded some topsoil at both sites. This left the soil surface particularly vulnerable to runoff and erosion, providing an ideal window of opportunity to test the effectiveness of hillslope stabilization treatments.

Three different treatments were tested. Wood shred mulch from forest thinning operations was tested both at Candelaria and Vilaflor. The mulch was applied at a rate of $14 \mathrm{Mg} \mathrm{ha}^{-1}(\sim 0.2-1 \mathrm{~cm}$ depth), but unlike in previous studies [4,5] fine fibers $(<2.5 \mathrm{~cm})$ were not removed to test the performance of the mulch when pre-processed in the most cost-effective way. The natural formation of pine needle mulch allowed this material to be tested at Candelaria. An average cover of $4 \mathrm{Mg} \mathrm{ha}^{-1}(\sim 3-4 \mathrm{~cm}$ depth) had accumulated here, with the litter showing some degree of physical breakdown, decomposition, and interlocking at the time of the rainfall simulations (4 months after the fire). Anionic PAM (Superfloc A-110 Flocculent, manufactured by Kemira Water Solutions BV, The Netherlands) was tested for its performance at Vilaflor. This site was ideal for this purpose as it exhibited extremely water-repellent soil conditions. This PAM was applied manually as granules at a rate of $50 \mathrm{~kg} \mathrm{ha}^{-1}$. 
At Candelaria, 15 plots $\left(0.25 \mathrm{~m}^{2}\right)$ were established in planar south-facing slopes of comparable gradient (40-50\%) and burn severity (low-moderate). Natural needle cover was removed from 10 plots to generate wood shred and control plots. Thus, wood shreds were manually applied to 5 bare plots and 5 plots were left uncovered as controls. At the remaining 5 plots the natural cover of pine needle litter was left intact (Figure 2). At Vilaflor, 12 plots $\left(0.25 \mathrm{~m}^{2}\right)$ were established in planar west-facing slopes of comparable gradient (30-40\%) and burn severity (low-moderate). Wood shreds were manually applied to 5 plots and PAM to 3 plots. The remaining 4 plots were left untreated as controls (Figure 2). At Candelaria, plots were bounded by a $0.25 \mathrm{~m}^{2}$ steel frame inserted into the soil to approximately $3 \mathrm{~cm}$ in depth to prevent in- and outflow of water from the plot. At Vilaflor, the rock cover did not allow insertion of the metal frame and polyurethane foam and silicone were instead used to build and seal the plot boundaries using the metal frame as mold (Figure 2). At both sites, the frames had an outlet down slope that was levelled with the soil surface to collect the runoff samples.
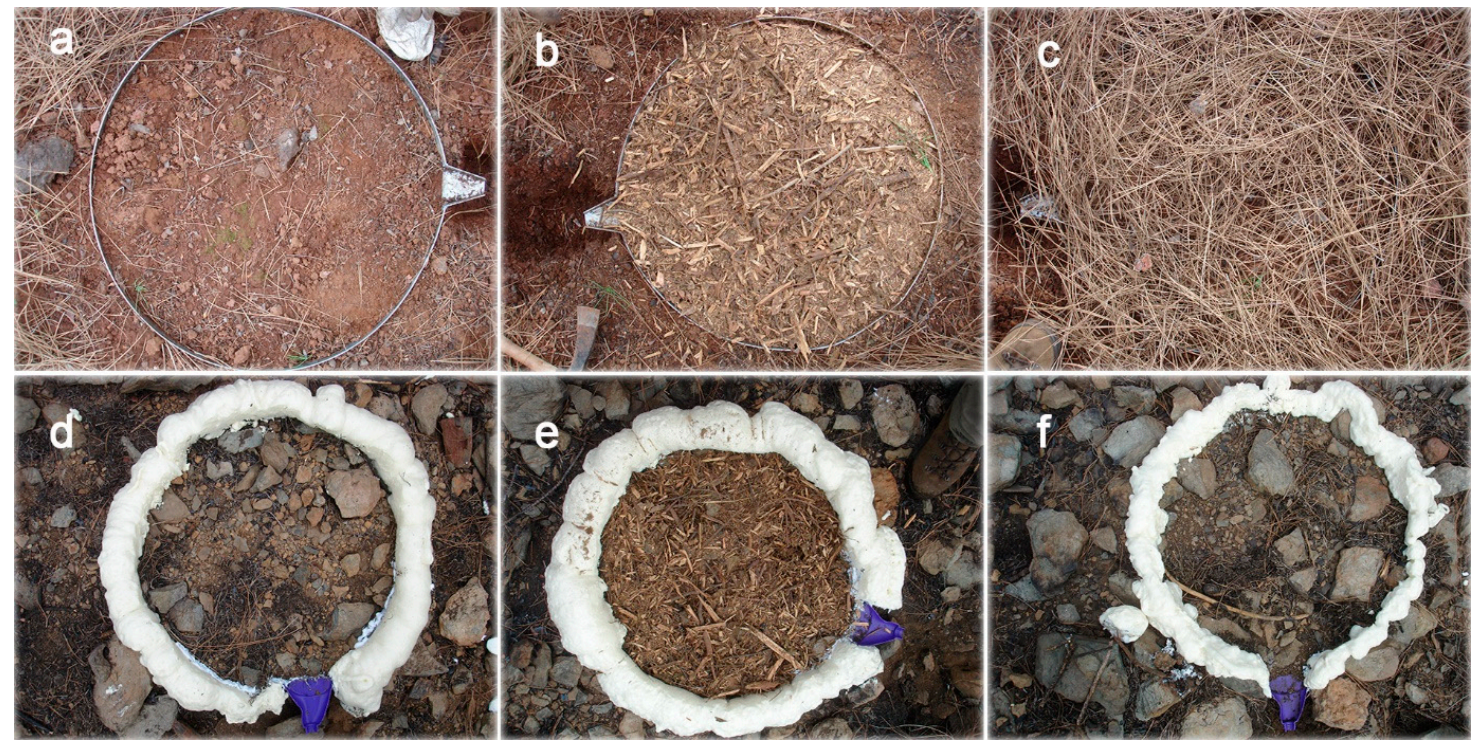

Figure 2. Treated and untreated plots at Candelaria (top) and Vilaflor (bottom). Control (a), wood shred mulch (b), and pine needle mulch (c) plots at Candelaria. Control (d), wood shred mulch (e), and polyacrylamide (PAM) (f) plots at Vilaflor.

\subsection{Measurements}

Ground cover was determined from pictures taken to the plots before the simulations and after the treatments were applied. For each $0.25 \mathrm{~m}^{2}$ plot, ground cover type was determined in a 35-point intercept grid. Cover types comprised bare soil, ash/char, gravel/rock, and litter/mulch.

Rainfall simulations were performed on the plots using a nozzle-type portable rainfall simulator similar to the one described by Cerdà et al. [18]. The rainfall simulator was set at $2 \mathrm{~m}$ above the plot and a wind screen was used to reduce the effect of winds on rainfall pattern. The rainfall intensity was set at $55 \mathrm{~mm} \mathrm{~h}^{-1}$ for $30 \mathrm{~min}$ (15-year average recurrence interval for the study area) and measured both outside the plot during each rainfall simulation and into the plot at the end of each run. Samples were taken continuously at the outlet in $500 \mathrm{~mL}$ bottles at $5 \mathrm{~min}$ intervals or shorter when the bottles were full. Sample volume was measured in the field and then filtered and dried for $48 \mathrm{~h}$ in the laboratory to determine the amount of sediment. Time to runoff ( $\mathrm{min}$ ), infiltration and runoff depth $(\mathrm{mm})$, final infiltration and runoff rates when the steady-state was reached $\left(\mathrm{mm} \mathrm{h}^{-1}\right)$, total sediment yield $\left(\mathrm{g} \mathrm{m}^{-2} \mathrm{~h}^{-1}\right)$, and sediment concentration $\left(\mathrm{g} \mathrm{L}^{-1}\right)$ were calculated. All the parameters except time to runoff and sediment concentration were corrected for slope angle by calculating the projected horizontal area of the plot. 


\subsection{Laboratory Analysis}

At each site, 5 topsoil samples $(0-2 \mathrm{~cm})$ were taken in the proximity of the plots to determine soil properties. Bulk density was measured on an oven-dried weight basis of a $250 \mathrm{~cm}^{3}$ core sample taken at field-moisture conditions [19]. The samples were air-dried and passed through a $2 \mathrm{~mm}$ sieve prior to further analysis. Soil organic carbon (SOC) was determined by dichromate oxidation [20]. Particle-size distribution (particles $<2 \mathrm{~mm}$ ) was determined using the densimeter method [21]. Aggregate stability was measured by wet sieving bulk soil samples in a $0.2 \mathrm{~mm}$ mesh according to Bartoli et al. [22]. Water repellency was determined using the Water Drop Penetration Time test (WDPT) [23].

\subsection{Statistical Methods}

SPSS version 22.0.0 was used for the statistical analysis of the results obtained. Data were analyzed for normality and homogeneity of variance, and transformed using the Box-Cox family of transformations when appropriate $(\lambda=0$ for sediment yield and $\lambda=-1$ for sediment delivery). One-way analysis of variance test (ANOVA) was used to evaluate the effectiveness of pine needle mulch and PAM (only applied to one site), and to compare soil properties between sites. Two-way ANOVA was used to test the differences between factors (site and treatment). Tukey's honest significant difference (HSD) post-hoc test was run to define homogenous subsets. A simple main effects test was performed to compare all pairs of levels of one factor for each level of all the other factors. Correlations between ground cover and runoff-erosion parameters were examined by Pearson-r correlation.

\section{Results}

\subsection{Soil Properties and Ground Cover}

The study sites exhibited contrasting soil properties, which has implications for their hydrological and erosional responses (Table 1 and Figure 3). The mean initial soil moisture immediately prior to rainfall simulations at Candelaria was higher than at Vilaflor $(23.3 \%$ vs. $7.3 \%$, respectively) $(p<0.001)$. The proportion of water stable aggregates was higher at Candelaria than Vilaflor ( $56 \%$ vs. $15 \%$, respectively) $(p<0.001)$. Stone content and bulk density showed lower values at Candelaria ( $25 \%$ vs. $43 \%$ and 710 vs. $1044 \mathrm{~kg} \mathrm{~m}^{-3}$, respectively) ( $p=0.001$ and $p=0.011$, respectively). While soils at Candelaria were classified as non-water repellent (mean WDPT $<1 \mathrm{~s}$ ), those at Vilaflor were extremely water repellent (mean WDPT $>5 \mathrm{~h}$ with $20 \%$ of the drops remaining longer than $10 \mathrm{~h})(p<0.001)$. Both soils were classified as loam.

Table 1. Mean and standard deviation (SD) of the main soil properties of the selected sites: gravimetric water content (GWC); soil organic carbon (C); water stable aggregates and soil water repellency. Different letters in each column indicate $p$ values $<0.05$ for differences between sites.

\begin{tabular}{ccccccc}
\hline \multirow{2}{*}{ Site } & GWC & $\mathbf{C}$ & Bulk Density & Water Stable Aggregates & Soil Water Repellency \\
\cline { 3 - 7 } & & $\%$ & $\%$ & $\mathbf{M g ~ m}^{-3}$ & $\%$ & s \\
\hline \multirow{2}{*}{ Candelaria } & Mean & $23.3 \mathrm{a}$ & $7.2 \mathrm{a}$ & $0.7 \mathrm{a}$ & $56.0 \mathrm{a}$ & $0.2 \mathrm{a}$ \\
& $S D$ & 2.6 & 4.1 & 0.2 & 7.1 & 0.0 \\
\hline \multirow{2}{*}{ Vilaflor } & Mean & $7.3 \mathrm{~b}$ & $8.9 \mathrm{a}$ & $1.0 \mathrm{~b}$ & $15.3 \mathrm{~b}$ & $25,283.5 \mathrm{~b}$ \\
& $S D$ & 2.7 & 5.2 & 0.2 & 2.8 & $14,403.8$ \\
\hline
\end{tabular}

Ground cover in the control plots (Figure 3) was lower at Candelaria than Vilaflor (22\% vs. $68 \%$ ) $(p<0.001)$ due to the significantly higher cover provided by gravel and rock at Vilaflor $(6 \%$ vs. $55 \%)$ $(p=0.005)$. Other categories of ground cover did not show statistical evidence for a difference between sites for control plots. The application of wood shred mulch and pine needle mulch resulted in lower proportion of bare soil in both sites when compared to control plots ( $4 \%$ and $14 \%$ for wood shreds and needles, respectively, at Candelaria, and $<1 \%$ for wood shreds at Vilaflor $)(p<0.001)$. Gravel and rock cover did not differ between control and wood shred plots at Vilaflor $(p=0.253)$. 
A visual inspection of the mulch plots at Vilaflor and Candelaria showed that in the former the wood shreds were mainly located between the rocks that covered the soil while those rocks remained uncovered. This layout resulted in a deeper wood shred layer than at Candelaria, where shreds were homogeneously distributed on the plot area. No statistical evidence for a difference was observed between ground cover for wood shred and pine needle treated plots at Candelaria. As expected, the ground cover was not affected in the plots treated with PAM at Vilaflor, which showed similar values to the control plots.

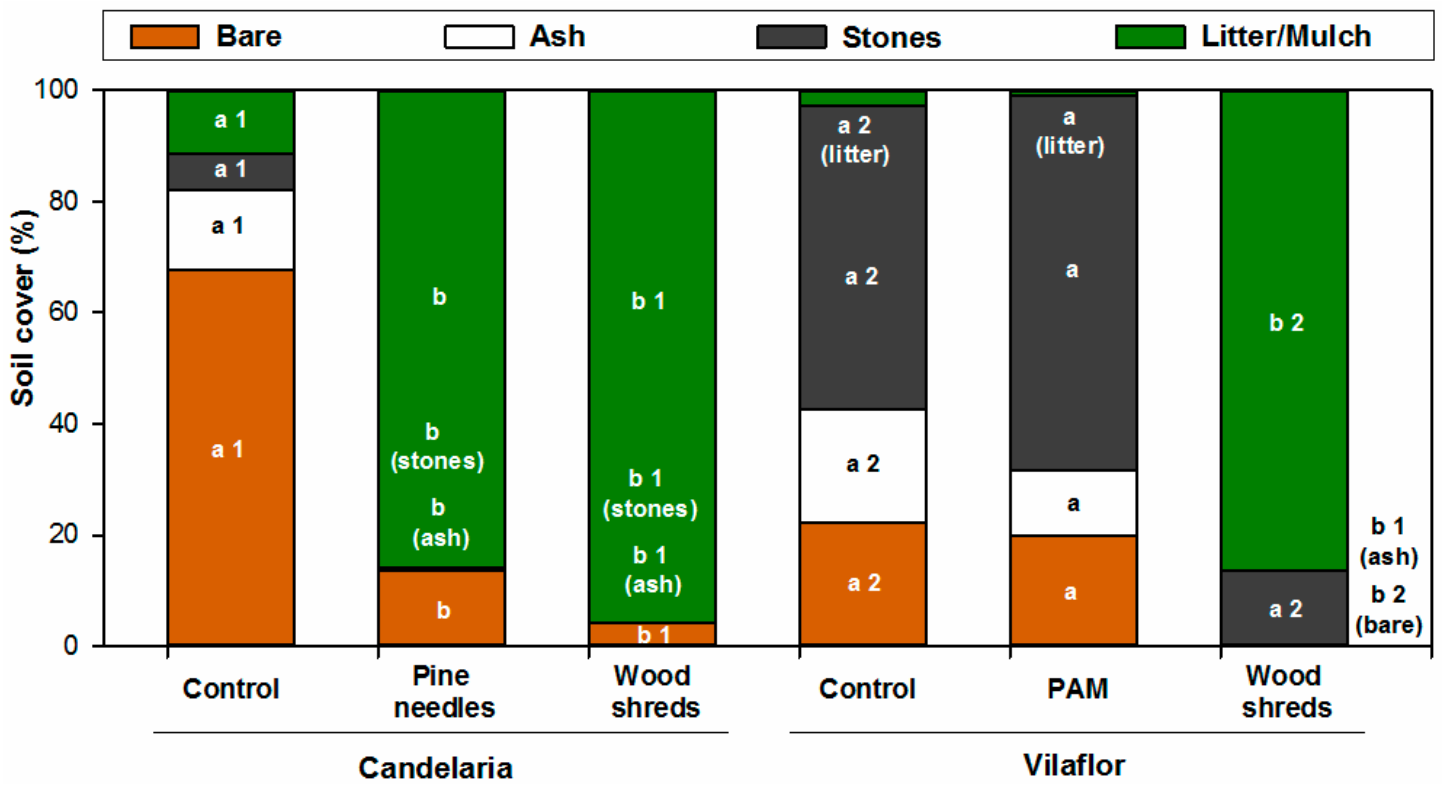

Figure 3. Mean values of ground cover for the hillslope stabilization treatments evaluated. Different letters in each ground cover type indicate $p$ values lower than 0.05 for differences between treatments for the specific cover types and site. Different numbers in each ground cover type indicate $p$ values lower than 0.05 for differences between sites for the specific treatment and ground cover type.

\subsection{Runoff and Erosion Response}

\subsubsection{Differences between Control Plots}

The runoff at the control plots started shortly after the rainfall at both sites (2.5 min at Candelaria and 1.6 min at Vilaflor to produce runoff) (Table 2). A very distinctive hydrological and erosional response between sites was evident after the runoff started. Final infiltration rate was higher at Candelaria than at Vilaflor (29 vs. $14 \mathrm{~mm} \mathrm{~h}^{-1}$ ) whereas final runoff rate was lower (26 vs. $41 \mathrm{~mm} \mathrm{~h}^{-1}$ ), these differences are supported by moderately strong statistical evidence $(p=0.024$ and $p=0.017$, respectively). The infiltration depth reached $18 \mathrm{~mm}$ at Candelaria as compared to lower values of $8 \mathrm{~mm}$ at Vilaflor. As a result, significantly higher runoff depth was observed at Vilaflor compared to Candelaria (18 mm vs. $10 \mathrm{~mm}$ ). Both for infiltration and runoff depths, the statistical tests showed strong evidence for a difference ( $p<0.001$ in both cases).

Despite the enhanced runoff in control plots of Vilaflor, the sediment concentration in the runoff and the sediment yield showed significantly higher values in control plots of Candelaria as compared to Vilaflor (1.8 vs. $0.4 \mathrm{~g} \mathrm{~L}^{-1}$ and 28 vs. $12 \mathrm{~g} \mathrm{~m}^{-2} \mathrm{~h}^{-1}$, respectively). The strength of evidence for a difference between sites was strong for sediment concentration $(p=0.001)$ and moderate-weak regarding sediment yield ( $p=0.045)$. 
Table 2. Mean and standard deviation (SD) values of runoff and erosion parameters evaluated: time to runoff; final infiltration rate; infiltration depth; final runoff rate; runoff depth; sediment yield and; sediment concentration. Different letters in each column and site indicate $p$ values lower than 0.05 for differences between treatments in the specific site. Different numbers in each column and treatment indicate $p$-values $<0.05$ for differences between sites for the specific treatment.

\begin{tabular}{|c|c|c|c|c|c|c|c|c|c|}
\hline \multirow{2}{*}{\multicolumn{3}{|c|}{ Site/Treatment }} & $\begin{array}{l}\text { Time to } \\
\text { Runoff }\end{array}$ & $\begin{array}{c}\text { Infiltration } \\
\text { Rate }\end{array}$ & $\begin{array}{l}\text { Infiltration } \\
\text { Depth }\end{array}$ & $\begin{array}{c}\text { Runoff } \\
\text { Rate }\end{array}$ & $\begin{array}{l}\text { Runoff } \\
\text { Depth }\end{array}$ & $\begin{array}{l}\text { Sediment } \\
\text { Yield }\end{array}$ & $\begin{array}{c}\text { Sediment } \\
\text { Concentration }\end{array}$ \\
\hline & & & $\min$ & $\mathrm{mm} \mathrm{h}^{-1}$ & $\mathrm{~mm}$ & $\mathrm{~mm} \mathrm{~h}^{-1}$ & $\mathrm{~mm}$ & $\underset{h^{-1}}{\mathrm{~g} \mathrm{~m}^{-2}}$ & $\mathrm{~g} \mathrm{~L}^{-1}$ \\
\hline \multirow{3}{*}{ Candelaria } & Control & $\begin{array}{l}\text { Mean } \\
S D\end{array}$ & $\begin{array}{c}2.5 \mathrm{ab} 1 \\
0.9\end{array}$ & $\begin{array}{c}29.2 \mathrm{a} 1 \\
5.4\end{array}$ & $\begin{array}{c}17.8 \mathrm{a} 1 \\
1.9\end{array}$ & $\begin{array}{c}25.6 \text { a1 } \\
5.3\end{array}$ & $\begin{array}{c}9.7 \mathrm{a} 1 \\
1.9\end{array}$ & $\begin{array}{c}27.8 \mathrm{a} 1 \\
8.2\end{array}$ & $\begin{array}{c}1.8 \mathrm{a} 1 \\
0.6\end{array}$ \\
\hline & $\begin{array}{l}\text { Wood } \\
\text { shreds }\end{array}$ & $\begin{array}{c}\text { Mean } \\
S D\end{array}$ & $\begin{array}{c}4.5 \mathrm{~b} 1 \\
1.6\end{array}$ & $\begin{array}{c}45.3 \mathrm{~b} 1 \\
6.8\end{array}$ & $\begin{array}{c}23.8 \mathrm{~b} 1 \\
2.4\end{array}$ & $\begin{array}{c}9.7 \mathrm{~b} 1 \\
6.8\end{array}$ & $\begin{array}{c}3.7 \mathrm{~b} 1 \\
2.4\end{array}$ & $\begin{array}{c}2.3 \mathrm{~b} 1 \\
1.4\end{array}$ & $\begin{array}{c}0.4 \mathrm{~b} 1 \\
0.0\end{array}$ \\
\hline & $\begin{array}{c}\text { Pine } \\
\text { needles }\end{array}$ & $\begin{array}{c}\text { Mean } \\
S D\end{array}$ & $\begin{array}{c}1.9 \mathrm{a} \\
0.6\end{array}$ & $\begin{array}{c}45.4 \mathrm{~b} \\
13.4\end{array}$ & $\begin{array}{c}24.0 \mathrm{~b} \\
5.1\end{array}$ & $\begin{array}{c}11.3 \mathrm{~b} \\
11.6\end{array}$ & $\begin{array}{c}4.4 \mathrm{~b} \\
4.3\end{array}$ & $\begin{array}{c}3.5 \mathrm{~b} \\
3.0\end{array}$ & $\begin{array}{c}0.6 \mathrm{~b} \\
0.3\end{array}$ \\
\hline \multirow{3}{*}{ Vilaflor } & Control & $\begin{array}{c}\text { Mean } \\
S D\end{array}$ & $\begin{array}{c}1.6 \mathrm{a} 1 \\
1.0\end{array}$ & $\begin{array}{c}13.6 \mathrm{ab} 2 \\
7.3\end{array}$ & $\begin{array}{c}7.8 \mathrm{a} 2 \\
2.4\end{array}$ & $\begin{array}{c}41.4 \mathrm{a} 2 \\
7.3\end{array}$ & $\begin{array}{c}18.0 \mathrm{a} 2 \\
0.9\end{array}$ & $\begin{array}{c}12.3 \mathrm{a} 2 \\
2.1\end{array}$ & $\begin{array}{c}0.4 \mathrm{ab} 2 \\
0.1\end{array}$ \\
\hline & $\begin{array}{l}\text { Wood } \\
\text { shreds }\end{array}$ & $\begin{array}{c}\text { Mean } \\
S D\end{array}$ & $\begin{array}{c}3.1 \mathrm{a} 1 \\
1.8\end{array}$ & $\begin{array}{c}25.5 \mathrm{~b} 2 \\
13.3\end{array}$ & $\begin{array}{c}17.4 \mathrm{~b} 2 \\
3.2\end{array}$ & $\begin{array}{c}29.2 \mathrm{~b} 2 \\
13.3\end{array}$ & $\begin{array}{c}10.1 \mathrm{~b} 2 \\
3.2\end{array}$ & $\begin{array}{c}4.7 \mathrm{~b} 2 \\
1.9\end{array}$ & $\begin{array}{c}0.3 \mathrm{~b} 1 \\
0.1\end{array}$ \\
\hline & PAM & $\begin{array}{l}\text { Mean } \\
S D\end{array}$ & $\begin{array}{c}1.5 \mathrm{a} \\
0.8\end{array}$ & $\begin{array}{c}5.2 \mathrm{a} \\
4.2\end{array}$ & $\begin{array}{c}6.9 \mathrm{a} \\
3.4\end{array}$ & $\begin{array}{c}49.4 \mathrm{a} \\
3.9\end{array}$ & $\begin{array}{c}20.6 \mathrm{a} \\
3.4\end{array}$ & $\begin{array}{c}22.3 \mathrm{a} \\
7.9\end{array}$ & $\begin{array}{c}0.6 \mathrm{a} \\
0.2\end{array}$ \\
\hline
\end{tabular}

\subsubsection{Effectiveness of the Selected Treatments When Compared to Control Plots}

At both sites, wood shred plots showed greater infiltration depths (34\% at Candelaria and $124 \%$ at Vilaflor) ( $p=0.023$ at Candelaria and $p=0.001$ at Vilaflor) and less runoff depth (62\% at Candelaria and $44 \%$ at Vilaflor) ( $p=0.010$ at Candelaria and $p=0.002$ at Vilaflor) compared to control plots. The final infiltration rate was higher in both sites for wood shred treated plots when compared to the controls (55\% at Candelaria and $88 \%$ at Vilaflor), although the strength of evidence for a difference was moderate-weak at Candelaria $(p=0.042)$ and no evidence was found at Vilaflor $(p=0.215)$. The final runoff rate was lower in the wood mulch plots (62\% at Candelaria and $30 \%$ at Vilaflor). The strength of evidence for a difference was moderate-weak at Candelaria $(p=0.034)$ and very weak at Vilaflor $(p=0.165)$. Wood mulch plots showed larger values of time to runoff $(80 \%$ at Candelaria and $100 \%$ at Vilaflor) although the statistical evidence for difference was very weak due to the high variability of the results ( $p=0.105$ at Candelaria and $p=0.183$ at Vilaflor). Regarding erosion processes, wood shred plots showed lower values of sediment yield when compared to control plots in both sites $(92 \%$ at Candelaria and $61 \%$ at Vilaflor), whereas it only showed lower values of sediment concentration at Candelaria (78\%). The strength for those differences was strong at Candelaria $(p<0.001$ for sediment yield and $p=0.001$ for sediment concentration) and moderate-weak at Vilaflor $(p=0.041)$.

The needle mulch tested at Candelaria had a similar effect to wood shreds. The infiltration depth and the final infiltration rate were higher in plots with needle cover in comparison to controls $(35 \%$ and $55 \%$, respectively), whereas runoff depth and final runoff rate were lower (55\% and $56 \%$, respectively). The runoff depth showed moderate evidence for difference $(p=0.025)$, whereas it was moderate-weak for infiltration depth, final infiltration rate, and final runoff rate $(p=0.019, p=0.041$ and $p=0.064$, respectively). Time to runoff did not differ between control and plots covered by needles $(p=0.820)$. The needle cover plots showed less sediment concentration and sediment yield when compared to control plots ( $64 \%$ and $87 \%$, respectively), with moderate-weak evidence for a difference for the former $(p=0.033)$ and a strong one for the latter $(p<0.001)$. 
Plots treated with PAM, tested only at Vilaflor, showed lower final infiltration rate (62\%) and higher values of the sediment concentration and yield (51\% and $82 \%$, respectively). However, the evidences for differences were very weak given the high variability of the results obtained for PAM.

\subsubsection{Performance of Wood Based Mulch in Contrasting Volcanic Soils}

Final infiltration rate and infiltration depth were higher in plots with wood shreds at Candelaria when compared to plots at Vilaflor with the same treatment (78\% and 37\% higher, respectively). Accordingly, the final runoff rate and runoff depth showed lower values in plots with wood shreds at Candelaria ( $67 \%$ and $64 \%$ lower, respectively). The evidence for a difference was strong both for infiltration ( $p=0.004$ for rate and $p=0.005$ for depth) and for runoff parameters ( $p=0.003$ for rate and $p=0.002$ for depth).

Sediment yield was lower in plots with wood shred at Candelaria than at Vilaflor ( $52 \%$ lower) $(p=0.026)$, although control plots showed the opposite relationship. No major differences in sediment concentration were observed.

\subsubsection{Comparison between Treatments}

When comparing the performance of wood shreds and pine needles at Candelaria, both treatments showed similar effectiveness. Time to runoff, lower in needle mulch plots, was the only parameter that showed statistical evidence for a difference $(57 \%, p=0.019)$.

PAM applied at Vilaflor showed a very distinctive effect on the runoff-erosion processes when compared to wood-based mulch. Values of infiltration depth and final infiltration rate were lower for PAM application when compared to wood shred plots (60\% and $80 \%$ lower, respectively), with strong evidence for a difference for the former $(p<0.001)$ and moderate for the latter $(p=0.025)$. Accordingly, runoff depth and final runoff rate were significantly higher with PAM application $(105 \%$ and $69 \%$, respectively), with strong evidence for a difference for the former $(p<0.001)$ and moderate for the latter $(p=0.018)$. PAM plots also showed higher values of both sediment concentration and yield when compared to wood shred mulch (95\% and $371 \%$, respectively), with strong evidence for a significant difference ( $p=0.008$ and $p=0.003$, respectively).

\subsubsection{Influence of Ground Cover on Runoff and Erosion}

Ground cover (i.e., the proportion of bare soil) was directly related to runoff depth at Vilaflor, sediment concentration and sediment yield (Figure 4). Since sediment yield is the product of runoff depth and sediment concentration, sediment yield at Candelaria is more affected by the impact of bare soil in sediment concentration, whereas at Vilaflor the effect of bare soil on runoff is more relevant for affecting sediment yield. 

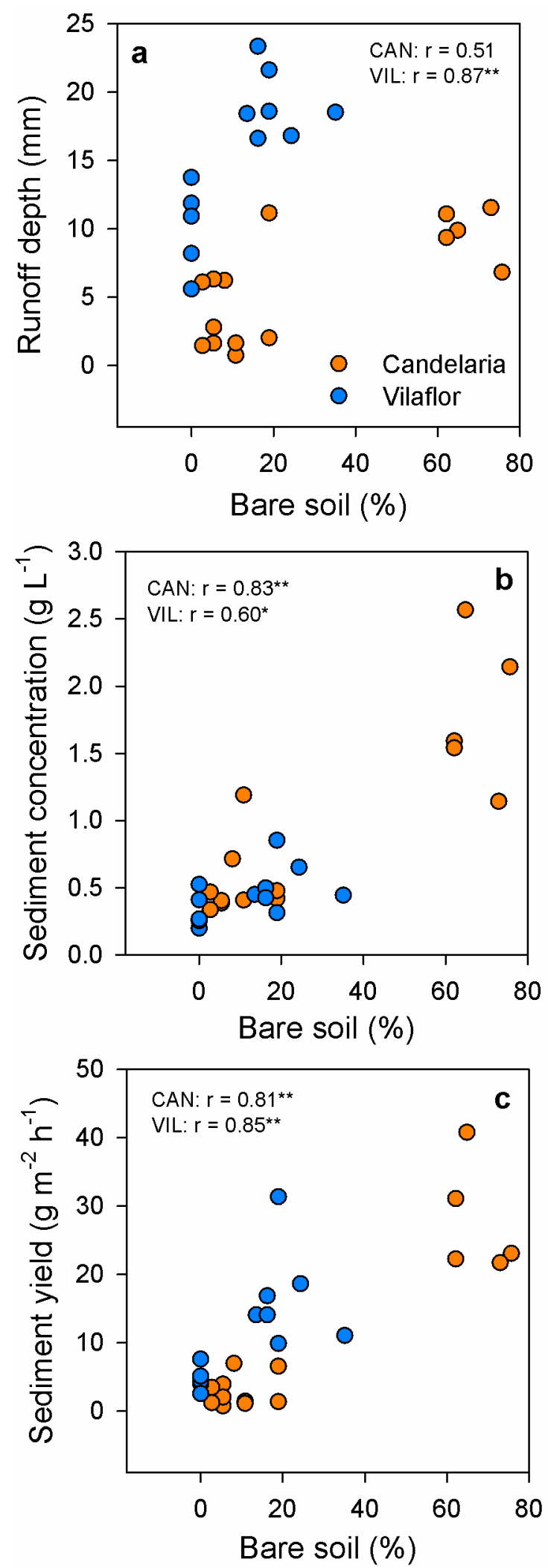

Figure 4. Influence of ground cover on runoff and erosion at Candelaria (CAN—orange dots) and Vilaflor (VIL—blue dots): (a) Runoff depth; (b) sediment concentration, and; (c) sediment yield plotted against bare soil. Pearson-r coefficients are also given. 


\section{Discussion}

\subsection{Runoff and Erosion in the Control Plots}

Candelaria showed the typical response of a volcanic soil affected by low-moderate soil burn severity [14]. Runoff and interrill erosion values were significantly higher than those reported for undisturbed Andisols [15,24,25], but still considerably lower than those of volcanic soils affected by high soil burn severity [8,14,15] or other fire-affected soil types from the Mediterranean area [9,26,27], Northwestern Spain and Portugal [9,10,28], Western USA [4,5,8] and Australia [29,30]. Differences between this study and the previous work listed above can be explain by a number of other factors. For example, the higher porosity and structural stability of volcanic soils in undisturbed conditions [31,32], which could still be present to some extent after a low-moderate soil burn severity fire.

Differences regarding site conditions and methods used to evaluate runoff-erosion process could also explain some differences. For example, the soil burn severity in this study was lower than the burn severity described in other studies and, thus, the impact of fire on key hillslope and soil properties that control the soil hydrological and erosional response such as ground cover, aggregate stability or water repellency can also be expected to be lower. The occurrence of a storm event before this study could also have led to some transport of the easily erodible soil and ash particles available at the soil surface after the fire and, thus, to the lower erosion values obtained during the rainfall simulations. The lower erosion values can be also attributed to the lower rainfall intensity and duration used in this study when compared to other studies (55 vs. up to $100 \mathrm{~mm} \mathrm{~h}^{-1}$ and $30 \mathrm{~min}$ here vs. up to $1 \mathrm{~h}$ ), that results in comparatively less kinetic energy and rainfall erosivity in the current study. Additionally, the larger plots used in some of the previous studies (up to $6 \mathrm{~m}^{2}$ compared with $0.24 \mathrm{~m}^{2}$ in this study) could have allowed for the development of other erosion features such as rills that may lead to higher sediment delivery.

Vilaflor, however, showed infiltration values substantially lower than those expected for this soil type and soil burn severity [14]. This response can be related mainly to the reduction of infiltration by: (i) the extreme water repellency of these soils [1], which prevented the infiltration of $20 \%$ of the water drops applied in the WDPT test for more than 10 hours, and; (ii) the reduction of the effective infiltration area due to the high proportion of gravel and stones into the soil profile (up to $50 \%$ in weight) [33].

Enhanced interrill erosion processes were expected in Vilaflor in accordance with their increased runoff and low soil structural stability. However, significantly lower values of sediment yield and sediment concentration in the runoff were obtained when compared to Candelaria. The high stone content and the presence of rills at Vilaflor indicates the high erodibility of this volcanic terrain and the occurrence of severe erosion events in the past. These events could have led to the loss of topsoil and increased rock and gravel cover (reaching 70\% in some plots) that currently protects the remaining soil aggregates against detachment and transport [33]. Additionally, the storm that occurred before this study could have partially reduced the availability of easily erodible soil and ash from the topsoil after the fire at Vilaflor. However, the needle cast at Candelaria could have protected the soil surface during the storm, leaving soil aggregates and ash particles intact and ready to be transported by the rainfall simulations.

\subsection{Treatment Effectiveness}

\subsubsection{Wood Shreds and Pine Needle Mulches}

Both wood shred and pine needle mulches significantly reduced the occurrence and magnitude of runoff and erosion processes at Candelaria. Wood shred mulch also significantly delayed the occurrence of runoff. Although numerous studies have tested and compared different mulch treatments to control erosion in the post-fire period, few have assessed their impact on the soil hydrological response. Where they have done so, authors commonly report slightly lower values of runoff in plots 
treated with pine needles $[8,26]$, wood shreds $[4,5]$ or straw mulch $[4,28,34]$ compared to control plots, although these differences were not significant. However, we know of only two previous studies that demonstrated a significant effect in reducing runoff $[6,35]$ as determined in the current study. Both studies were carried out in fire-affected areas of Portugal in loamy soils over metamorphic bedrock, which contrasts the volcanic soils examined in the current study.

Three combined processes could explain the delay and reduction of the runoff at the microplot scale observed in this study in the mulched plots: (i) the protection against raindrop impacts; (ii) the increase of water retention capacity, and; (iii) the increase of the effective surface area for infiltration.

The ground cover provided by the mulch protects the soil surface against raindrop impact, preventing aggregate breakdown, subsequent pore clogging, and reduction of infiltration rate and depth. This effect has been widely-reported for different soil types and ecosystem disturbances (see the comprehensive review by Prosdocimi et al. [36]).

Mulch treatments can also delay runoff occurrence and runoff depth by adsorbing water to the mulch particle surfaces and holding water in the increased surface roughness provided. Robichaud et al. [4] suggest low water retention capacity values for wood shred mulches and, thus, little effect on water holding capacity. However, it is important to bear in mind that, in our wood shred mulch, the fines had not been removed before its application in contrast to the studies of Foltz and Wagenbrenner [5] and Robichaud et al. [4]. We hypothesize that the presence of fines combined with coarse material in the wood shreds used here increases: (i) the soil-mulch contact as suggested by Pannkuk and Robichaud [8] for short pine needles, resulting in higher surface water storage capacity, and; (ii) the water retention capacity of the mulch due to the higher specific surface area provided by the fines in comparison to a coarse-only mulch. Additionally, Pannkuk and Robichaud [8] levelled and compacted the soil surface before the laboratory rainfall simulations, likely affecting the natural surface detention capacity of the soils and the positive impact of the mulch cover in this case.

The extra surface storage capacity provided by the mulch might increase the ponding area and, therefore, activate macropore flow in these newly ponded areas. This process has been previously described by Woods and Balfour [37] for thick ash layers in fire-affected soils. The abundance of macropores in volcanic soils such as Candalaria, suggested by its low bulk density and high aggregate stability, can enhance this process. Mulch treatments can also delay runoff occurrence and runoff depth by adsorbing water to the mulch particle surfaces and holding water in the increased surface roughness provided. Robichaud et al. [4] suggest low water-retention capacity values for wood shred mulches and, thus, little effect on water holding capacity. However, it is important to bear in mind that, in our wood shred mulch, the fines had not been removed before its application in contrast to the studies of Foltz and Wagenbrenner [5] and Robichaud et al. [4]. We hypothesize that the presence of fines combined with coarse material in the wood shreds used here increases: (i) the soil-mulch contact as suggested by Pannkuk and Robichaud [8] for short pine needles, resulting in higher surface water storage capacity, and; (ii) the water retention capacity of the mulch due to the higher specific surface area provided by the fines in comparison to a coarse-only mulch. Additionally, Pannkuk and Robichaud [8] levelled and compacted the soil surface before the laboratory rainfall simulations, likely affecting the natural surface detention capacity of the soils and the positive impact of the mulch cover in this property.

At Vilaflor, significant differences were found regarding infiltration and runoff depths, but not infiltration and runoff rates. We speculate that the substantial gravel and rock cover of these soils, which already protects against raindrop impact and prevents pore clogging, limits the further positive effect of the mulch cover on water infiltration rate. That aside, even if mulch cover maximizes ponding area in these soils, it is likely that their extreme water repellency can limit the potential increase of active macropore flow in these new ponded areas and the infiltration rate.

The results also showed a significant reduction of the sediment yields in mulched plots when compared to control plots at both studied areas. This effect has been previously attributed to the increase of ground cover provided by the wood-based mulch or straw mulch [4-7,35]. Pannkuk and 
Robichaud [8] reported poor effectiveness of long pine needle mulch on runoff control and sediment delivery due to the poor mulch-soil contact that prevented sediment trapping. However, our results showed that Canary Island pine needles, even when considered long $(20-30 \mathrm{~cm})$, have a significant effect on erosion reduction at the microplot scale. This is likely due to the natural interlocking and breakdown of the needles in the period between the fire and the rainfall simulations (four months). The resulting tightly packed mixture of different needle sizes can increase mulch-soil contact and enhance sediment trapping.

The decrease in sediment yield was related to a significant reduction in the runoff depth in the treated plots both at Candelaria and Vilaflor. However, only at Candelaria was it also accompanied by a significant reduction in the sediment concentration in the runoff. Raindrop impact can be considered the main cause of particle detachment and source of sediments in the runoff at the microplot scale. This process is reduced by the protection of the soil surface against the impact of raindrops and sediment entrapment provided by the increased cover and roughness of mulch treatments [36]. Accordingly, the results suggest that the large natural ground cover by rocks and gravels at Vilaflor can limit further positive effect of the mulch cover and in sediment concentration in the runoff.

\subsubsection{PAM-Treated Soils}

In contrast to what might have been expected, some plots treated with PAM showed considerably higher sediment yield and slightly higher runoff rate, runoff depth, and sediment concentration, although the differences were not significant when comparing PAM and control plots. Prats et al. [10] found slightly lower values of runoff, but higher sediment delivery after the application of PAM in water-repellent soils for microplots exposed to natural rainfall. In line with their results on runoff, Davidson et al. [11] reported a significant decrease in soil water repellency after the application of PAM and suggested that PAM molecules could be interacting with hydrophobic coated soil particles that flocculate and open interstitial channels that increase water infiltration. Other studies $[9,27]$, however, reported a significant increase in runoff and a decrease in sediment delivery during the first storm after the application of PAM to wettable soils using rainfall simulations. The authors attributed the results regarding erosion to the aggregating effect of PAM and the results on runoff to the reduction of infiltration rate due to the increase in water viscosity when the PAM was dissolved.

Our results show that the application of PAM to an extremely water repellent volcanic soil had no effect on runoff or erosion. This is probably because in this kind of soils the essential interaction between PAM and soil particles to increase aggregation or decrease water repellency is limited to a few preferential pathways where the infiltration takes place and not generally distributed across the soil surface. Lado et al. [27] reported that the reduction in infiltration was reverted in the second and successive simulated rain events due to the enhanced aggregate stability triggered by the interaction of dissolved PAM molecules and soil particles during the infiltration process. It is unclear whether this effect can be expected in an extremely water-repellent soil such as the one examined at Vilaflor due to the limited infiltration and interaction between PAM and soil.

\section{Conclusions and Wider Implications}

This study examined the runoff and erosion processes at the microplot scale in two burned areas with contrasting volcanic soils (wettable vs. extremely water repellent) and evaluated the effectiveness of wood shred mulch, pine needle mulch, and PAM in reducing runoff and erosion.

Wood shreds and pine needles showed high effectiveness in reducing runoff and erosion in the non-water repellent soil, likely due to the protection of the soil surface and additional water storage capacity. For the extremely water repellent soil, wood shreds were also effective in reducing fire-induced runoff-erosion risks in this vulnerable terrain type.

The similarly good performance of both treatments suggests that: (i) pine needle mulch can be a suitable alternative to the widely-used wood-based mulches as a hillslope stabilization treatment, and; (ii) that no additional treatment would be needed if a pine needle cast is still present or develops after 
a forest fire and provides sufficient ground cover. However, further research is needed to evaluate the threshold of ground cover by needle cast needed to provide effective protection against erosion.

Regarding its application as an erosion mitigation treatment, both wood-based and long-leaf needle mulches avoid some of the logistical, ecological and economic drawbacks of agricultural straw mulch including: (i) redistribution by wind due to their higher density; (ii) weed contamination; (iii) transport costs from the source or unavailability, as needles may be available locally and wood shreds can be obtained from burned trees or forest thinning residues [4-7,38]. Our results at the microplot scale suggest good performance of wood shreds when fine fibers were not eliminated, thus saving pre-processing time and costs. Additionally, the results suggest that the application rates, and cost, of mulch treatments for particularly stony soils could be lowered due to the natural cover and protection provided by the rocks and gravels. However, further research is needed to evaluate their effectiveness in volcanic soils at coarser scales (i.e., hillslope scales), particularly given the poor effectiveness of long pine needle mulch reported when rill erosion dominates [5].

The major decrease in runoff depth observed in extremely water-repellent soils treated with wood-shreds suggests that its application should be prioritized in these highly vulnerable scenarios. The application of this treatment could counteract the enhanced runoff response observed in untreated plots and wider evidence from the surrounding terrain that suggests the occurrence of major erosion processes at hillslope and catchment scale with potential damage to infrastructures downhill. Where soils are particularly stony, as was the case at Vilaflor, it is suggested that application rates of mulch treatments for stony soils could be lowered due to the natural cover and protection provided by the rocks and gravels, reducing application costs.

Regarding PAM, our results contrast with most previous observations and suggest instead that its application as granules may have no effect in extremely water-repellent soils. Further evaluation of its performance using alternative application methods that promote the interaction between PAM molecules and soil particles in extremely water-repellent soils is needed.

Acknowledgments: This research has been funded by the H2020 Marie Skłodowska-Curie Individual Fellowship 2014 "FireAndRiskPrevention" (project number 655993). Stefan H. Doerr acknowledges support via a Leverhulme Research Fellowship (RF-2016-456\2). The authors thank José María Sánchez Linaje and Juan Agulló Pérez (Cabildo de Tenerife) for the logistic support in the field and María Dolores del Castillo and Mary Garín (Universidad de La Laguna) for the laboratory assistance.

Author Contributions: Neris and Doerr designed the field experiment and carried out the rainfall simulations and sample collection. Neris performed the analysis of soil properties and ground cover, and the statistical analysis in collaboration with Notario del Pino. Neris and Doerr performed the interpretation of the data and the drafting of the manuscript. Neris, Doerr, Rodríguez-Rodríguez, Notario del Pino and Arbelo contributed to manuscript preparation.

Conflicts of Interest: The authors declare no conflict of interest.

\section{References}

1. Shakesby, R.A.; Doerr, S.H. Wildfire as a hydrological and geomorphological agent. Earth Sci. Rev. 2006, 74, 269-307. [CrossRef]

2. Robichaud, P.R.; Ashmun, L.E.; Sims, B.D. Post-Fire Treatment Effectiveness for Hillslope Stabilization; General Technical Report RMRS-GTR-240; USDA Forest Service, Rocky Mountain Research Station: Fort Collins, CO, USA, 2010; p. 62.

3. Larsen, I.J.; MacDonald, L.H.; Brown, E.; Rough, D.; Welsh, M.J.; Pietraszek, J.H.; Libohova, Z.; Benavides-Solorio, J.D.; Schaffrath, K. Causes of post-fire runoff and erosion: Water repellency, cover, or soil sealing? Soil Sci. Soc. Am. J. 2009, 73, 1393-1407. [CrossRef]

4. Robichaud, P.R.; Jordan, P.; Lewis, S.A.; Ashmun, L.E.; Covert, S.A.; Brown, R.E. Evaluating the effectiveness of wood shred and agricultural straw mulches as a treatment to reduce post-wildfire hillslope erosion in southern British Columbia, Canada. Geomorphology 2013, 197, 21-33. [CrossRef]

5. Foltz, R.B.; Wagenbrenner, N.S. An evaluation of three wood shred blends for post-fire erosion control using indoor simulated rain events on small plots. Catena 2010, 80, 86-94. [CrossRef] 
6. Prats, S.A.; MacDonald, L.H.; Monteiro, M.; Ferreira, A.J.D.; Coelho, C.O.A.; Keizer, J.J. Effectiveness of forest residue mulching in reducing post-fire runoff and erosion in a pine and a eucalypt plantation in north-central Portugal. Geoderma 2012, 191, 115-124. [CrossRef]

7. Fernandez, C.; Vega, J.A. Effects of mulching and post-fire salvage logging on soil erosion and vegetative regrowth in NW Spain. For. Ecol. Manag. 2016, 375, 46-54. [CrossRef]

8. Pannkuk, C.D.; Robichaud, P.R. Effectiveness of needle cast at reducing erosion after forest fires. Water Resour. Res. 2003, 39. [CrossRef]

9. Inbar, A.; Ben-Hur, M.; Sternberg, M.; Lado, M. Using polyacrylamide to mitigate post-fire soil erosion. Geoderma 2015, 239-240, 107-114. [CrossRef]

10. Prats, S.A.; dos Santos Martins, M.A.; Malvar, M.C.; Ben-Hur, M.; Keizer, J.J. Polyacrylamide application versus forest residue mulching for reducing post-fire runoff and soil erosion. Sci. Total Environ. 2014, 468, 464-474. [CrossRef] [PubMed]

11. Davidson, R.A.; Davidson, C.F.; Roa-Espinosa, A. Linear anionic polyacrylamide as an effective post-fire soil treatment: Understanding the chemistry and physical science. J. Soil Water Conserv. 2009, 64, 243-252. [CrossRef]

12. Neris, J.; Santamarta, J.; Doerr, S.; Prieto, F.; Agulló-Pérez, J.; García-Villegas, P. Post-fire soil hydrology, water erosion and restoration strategies in Andosols: A review of evidence from the Canary Islands (Spain). iFor. Biogeosci. For. 2016, 9, 583-592. [CrossRef]

13. Small, C.; Cohen, J.E. Continental physiography, climate, and the global distribution of human population. Curr. Anthropol. 2004, 45, 269-277. [CrossRef]

14. Neris, J.; Tejedor, M.; Fuentes, J.; Jiménez, C. Infiltration, runoff and soil loss in Andisols affected by forest fire (Canary Islands, Spain). Hydrol. Process. 2013, 27, 2814-2824. [CrossRef]

15. Morales, D.; Rostagno, C.M.; La Manna, L. Runoff and erosion from volcanic soils affected by fire: The case of Austrocedrus chilensis forests in Patagonia, Argentina. Plant Soil 2013, 370, 367-380. [CrossRef]

16. Soil Survey Staff. Soil Taxonomy - A Basic System of Soil Classification for Making and Interpreting Soil Surveys; Natural Resources Conservation Service, USDA: Washington, DC, USA, 1999; p. 869.

17. Parsons, A.; Robichaud, P.R.; Lewis, S.A.; Napper, C.; Clark, J.T. Field Guide for Mapping Post-Fire Soil Burn Severity; General Technical Report RMRS-GTR-243; U.S. Department of Agriculture, Forest Service, Rocky Mountain Research Station: Fort Collins, CO, USA, 2010; p. 49.

18. Cerdà, A.; Ibáñez, S.; Calvo, A. Design and operation of a small and portable rainfall simulator for rugged terrain. Soil Technol. 1997, 11, 163-170. [CrossRef]

19. Blake, G.R.; Hartge, K.H. Bulk density. In Methods of Soil Analysis Part I: Physical and Mineralogical Methods; Klute, A.K., Ed.; American Society of Agronomy—Soil Science Society of America: Madison, WI, USA, 1986; pp. 363-375.

20. Walkley, A.; Black, I.A. An examination of the Degtjareff method for determining soil organic matter, and a proposed modification of the chromic acid titration method. Soil Sci. 1934, 37, 29-38. [CrossRef]

21. Gee, G.W.; Bauder, J.W. Particle size-analysis. In Methods of Soil Analysis Part I. Physical and Mineralogical Methods; Klute, A., Ed.; American Society of Agronomy-Soil Science Society of America: Madison, WI, USA, 1986; pp. 383-411.

22. Bartoli, F.; Burtin, G.; Herbillon, A.J. Disaggregation and clay dispersion of Oxisols-Na resin, a recommended methodology. Geoderma 1991, 49, 301-317. [CrossRef]

23. Doerr, S.H. On standardizing the 'water drop penetration time' and the 'molarity of an ethanol droplet' techniques to classify soil hydrophobicity: A case study using medium textured soils. Earth Surface Process. Landf. 1998, 23, 663-668. [CrossRef]

24. Neris, J.; Tejedor, M.; Rodríguez, M.; Fuentes, J.; Jiménez, C. Effect of forest floor characteristics on water repellency, infiltration, runoff and soil loss in Andisols of Tenerife (Canary Islands, Spain). Catena 2013, 108, 50-57. [CrossRef]

25. La Manna, L.; Buduba, C.G.; Rostagno, C.M. Soil erodibility and quality of volcanic soils as affected by pine plantations in degraded rangelands of NW Patagonia. Eur. J. For. Res. 2016, 135, 643-655. [CrossRef]

26. Cerdà, A.; Doerr, S.H. The effect of ash and needle cover on surface runoff and erosion in the immediate post-fire period. Catena 2008, 74, 256-263. [CrossRef] 
27. Lado, M.; Inbar, A.; Sternberg, M.; Ben-Hur, M. Effectiveness of granular polyacrylamide to reduce soil erosion during consecutive rainstorms in a calcic regosol exposed to different fire conditions. Land Degrad. Dev. 2016, 27, 1453-1462. [CrossRef]

28. Fernández, C.; Vega, J.A.; Jimenez, E.; Vieira, D.C.S.; Merino, A.; Ferreiro, A.; Fonturbel, T. Seeding and mulching plus seeding effects on post-fire runoff, soil erosion and species diversity in Galicia (NW Spain). Land Degrad. Dev. 2012, 23, 150-156. [CrossRef]

29. Sheridan, G.J.; Lane, P.N.J.; Noske, P.J. Quantification of hillslope runoff and erosion processes before and after wildfire in a wet eucalyptus forest. J. Hydrol. 2007, 343, 12-28. [CrossRef]

30. Cawson, J.G.; Nyman, P.; Smith, H.G.; Lane, P.N.J.; Sheridan, G.J. How soil temperatures during prescribed burning affect soil water repellency, infiltration and erosion. Geoderma 2016, 278, 12-22. [CrossRef]

31. Perrin, J.L.; Bouvier, C.; Janeau, J.L.; Menez, G.; Cruz, F. Rainfall/runoff processes in a small peri-urban catchment in the Andes mountains. The Rumihurcu Quebrada, Quito (Ecuador). Hydrol. Process. 2001, 15, 843-854. [CrossRef]

32. Nanzyo, M.; Shoji, S.; Dahlgren, R. Physical characteristics of volcanic ash soils. In Volcanic Ash Soils: Genesis, Properties and Utilization; Shoji, S., Nanzyo, M., Dahlgren, R., Eds.; Elsevier Science Publishers B.V.: Amsterdam, The Netherlands, 1993; p. 288.

33. Poesen, J.; Lavee, H. Rock fragments in top soils-Significance and processes. Catena 1994, 23, 1-28. [CrossRef]

34. Robichaud, P.R.; Wagenbrenner, J.W.; Lewis, S.A.; Ashmun, L.E.; Brown, R.E.; Wohlgemuth, P.M. Post-fire mulching for runoff and erosion mitigation Part II: Effectiveness in reducing runoff and sediment yields from small catchments. Catena 2013, 105, 93-111. [CrossRef]

35. Prats, S.A.; Wagenbrenner, J.W.; Martins, M.A.S.; Malvar, M.C.; Keizer, J.J. Mid-term and scaling effects of forest residue mulching on post-fire runoff and soil erosion. Sci. Total Environ. 2016, 573, 1242-1254. [CrossRef] [PubMed]

36. Prosdocimi, M.; Tarolli, P.; Cerdà, A. Mulching practices for reducing soil water erosion: A review. Earth Sci. Rev. 2016, 161, 191-203. [CrossRef]

37. Woods, S.W.; Balfour, V.N. The effects of soil texture and ash thickness on the post-fire hydrological response from ash-covered soils. J. Hydrol. 2010, 393, 274-286. [CrossRef]

38. Badia, D.; Marti, C. Seeding and mulching treatments as conservation measures of two burned soils in the central Ebro valley, NE Spain. Arid Soil Res. Rehabil. 2000, 14, $219-232$. 